\title{
Will Debt Relief Make a Difference? \\ Impact and Expectations of the Multilateral Debt Relief Initiative \\ By Todd Moss
}

\begin{abstract}
The Multilateral Debt Relief Initiative (MDRI) is the latest phase of debt reduction for poor countries from the World Bank, the IMF, and the African Development Bank. The MDRI, which will come close to full debt reduction for at least 19 (and perhaps as many as 40) qualifying countries, is being presented as a momentous leap forward in the battle against global poverty. However, the analysis in this paper suggests that the actual gains may be more modest and elusive. This is not because, as some anti-debt campaigners fear, that the initiative is a mere accounting trick. Rather, the limited short-term financial impact of the MDRI on affected countries is because the debt service obligations being relieved were themselves relatively insignificant. For example, in 2004 the average African country in the program paid \$19 million in debt service to the World Bank, but received 10 times that amount in new Bank credit and more than 50 times as much in total aid. Just as importantly, finances are rarely the binding constraint on poverty and other development outcomes. This is not to say that the MDRI is futile. Indeed the impact could be considerable over the long-term, especially on the ability of creditors to be more selective in the future. But most of the impact of the MDRI will be long-term and difficult to measure. As such, expectations of the effect on indebted countries and development indicators should be kept modest and time horizons long.
\end{abstract}

The Center for Global Development is an independent think tank that works to reduce global poverty and inequality through rigorous research and active engagement with the policy community.

Use and dissemination of this Working Paper is encouraged, however reproduced copies may not be used for commercial purposes. Further usage is permitted under the terms of the Creative Commons License. The views expressed in this paper are those of the author and should not be attributed to the directors or funders of the Center for Global Development. 


\title{
Will Debt Relief Make a Difference? Impact and Expectations of the Multilateral Debt Relief Initiative
}

\author{
Todd Moss ${ }^{1}$ \\ Center for Global Development \\ Washington DC
}

May 23, 2006

\begin{abstract}
The Multilateral Debt Relief Initiative (MDRI) is the latest phase of debt reduction for poor countries from the World Bank, the IMF, and the African Development Bank. The MDRI, which will come close to full debt reduction for at least 19 (and perhaps as many as 40) qualifying countries, is being presented as a momentous leap forward in the battle against global poverty. However, the analysis in this paper suggests that the actual gains may be more modest and elusive. This is not because, as some anti-debt campaigners fear, that the initiative is a mere accounting trick. Rather, the limited short-term financial impact of the MDRI on affected countries is because the debt service obligations being relieved were themselves relatively insignificant. For example, in 2004 the average African country in the program paid $\$ 19$ million in debt service to the World Bank, but received 10 times that amount in new Bank credit and more than 50 times as much in total aid. Just as importantly, finances are rarely the binding constraint on poverty and other development outcomes. This is not to say that the MDRI is futile. Indeed the impact could be considerable over the long-term, especially on the ability of creditors to be more selective in the future. But most of the impact of the MDRI will be long-term and difficult to measure. As such, expectations of the effect on indebted countries and development indicators should be kept modest and time horizons long.
\end{abstract}

\footnotetext{
${ }^{1}$ Todd Moss (tmoss@cgdev.org) is a Research Fellow at the Center for Global Development in Washington DC. A version of this paper first appeared as "The G8's Multilateral Debt Relief Initiative and poverty reduction in Sub-Saharan Africa” in African Affairs, Volume 105, Number 419, April 2006. The author thanks Nancy Birdsall, Steve Radelet, and David Cowan for comments on an earlier draft, and Scott Standley for research assistance. All errors are solely those of the author.
} 


\section{Introduction}

In 2006 the World Bank, the International Monetary Fund (IMF), and the African Development Bank (AfDB) will implement the next major phase of debt reduction for poor countries. The plan, now known as the Multilateral Debt Relief Initiative (MDRI), was first agreed by the G8 in June 2005 and has since been approved by the boards of the international financial institutions. The IMF has already begun implementation, and the World Bank and AfDB will follow suit beginning in July 2006. The MDRI has promised it will erase 'as much as 100 percent' of the debts owed by qualifying countries, the vast majority of which are in sub-Saharan Africa. Although this is being presented as a momentous leap forward for Africa and the battle against global poverty, the actual gains may be more modest and elusive. Hopes for a transformative impact on poverty-or even a meaningful effect on the cash flow of African treasuries-are unlikely to be realized. This does not imply that the MDRI is meaningless, but rather that the potential benefits are far from certain, likely to be long-term, and are not of the kind that many activists or observers may be expecting.

\section{Origins of Africa's debt burden}

For much of the post-independence period Africa has seen rising debt levels, at least up until the mid-1990s. In 1970 the external public or publicly-guaranteed debt stock for all of sub-Saharan Africa was just $\$ 5.7$ billion (or \$22 billion in 2003 dollars). ${ }^{2}$ This grew steadily throughout the 1980 s and peaked at $\$ 190$ billion in 1995 before settling at around $\$ 177$ billion at end-2003 (see Figure 1). This represented a rise from about 13 percent of regional GNI to over 100 percent by the mid-1990s before dropping to around 70 percent in 2003. At the same time, the debt service payments increased from about $\$ 2$ billion (2003 dollars) in 1970 to over $\$ 12$ billion in 1985 before sloping back down. The debt service ratio also rose and then fell roughly in parallel (see Figure 2).

\footnotetext{
${ }^{2}$ All aggregate debt figures exclude South Africa. The main source for debt data used throughout this section is the World Bank's Global Development Finance.
} 


\section{Figure 1}

Sub-Saharan African Debt Stock

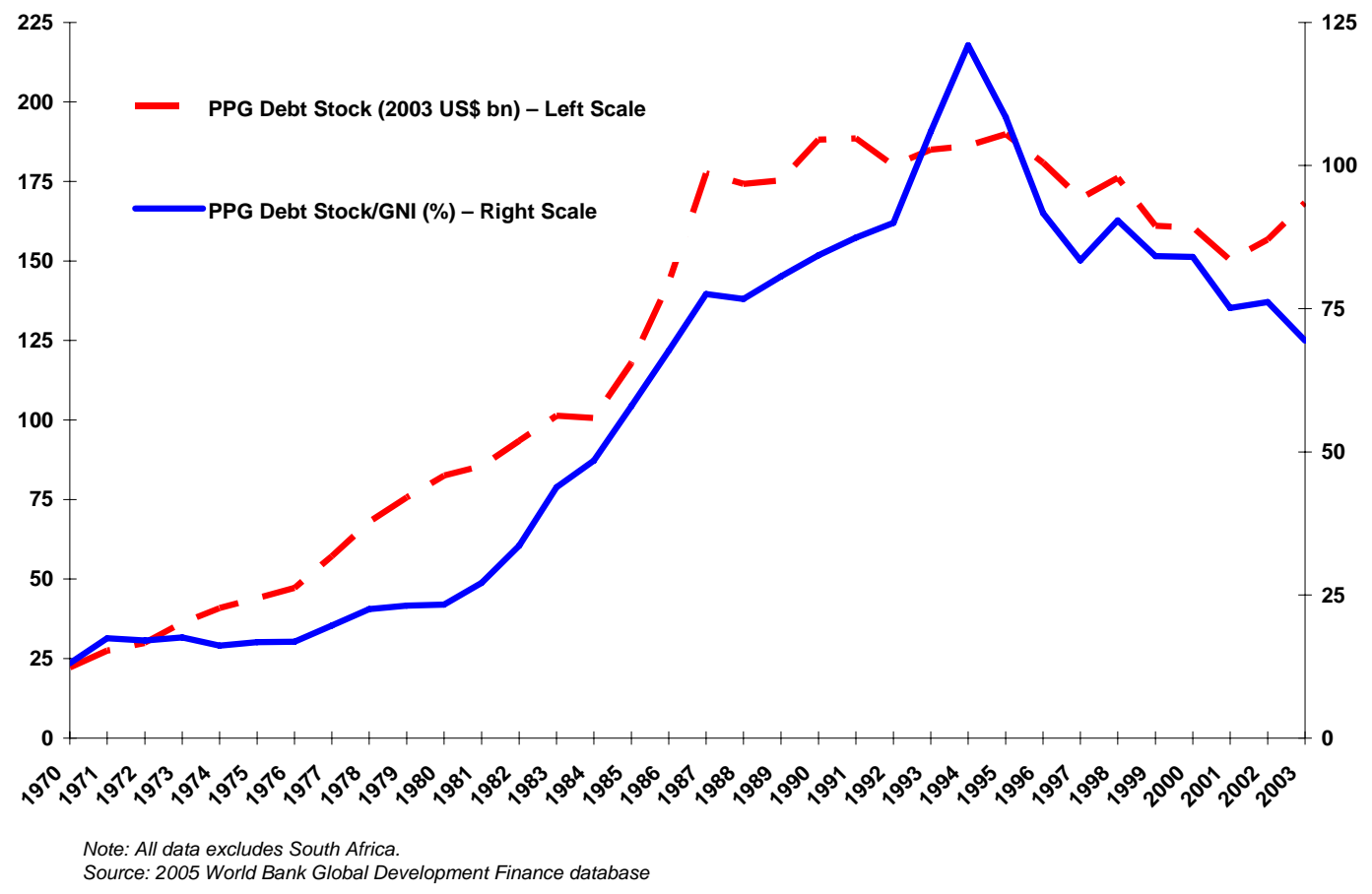

Figure 2

\section{Sub-Saharan African Debt Service}

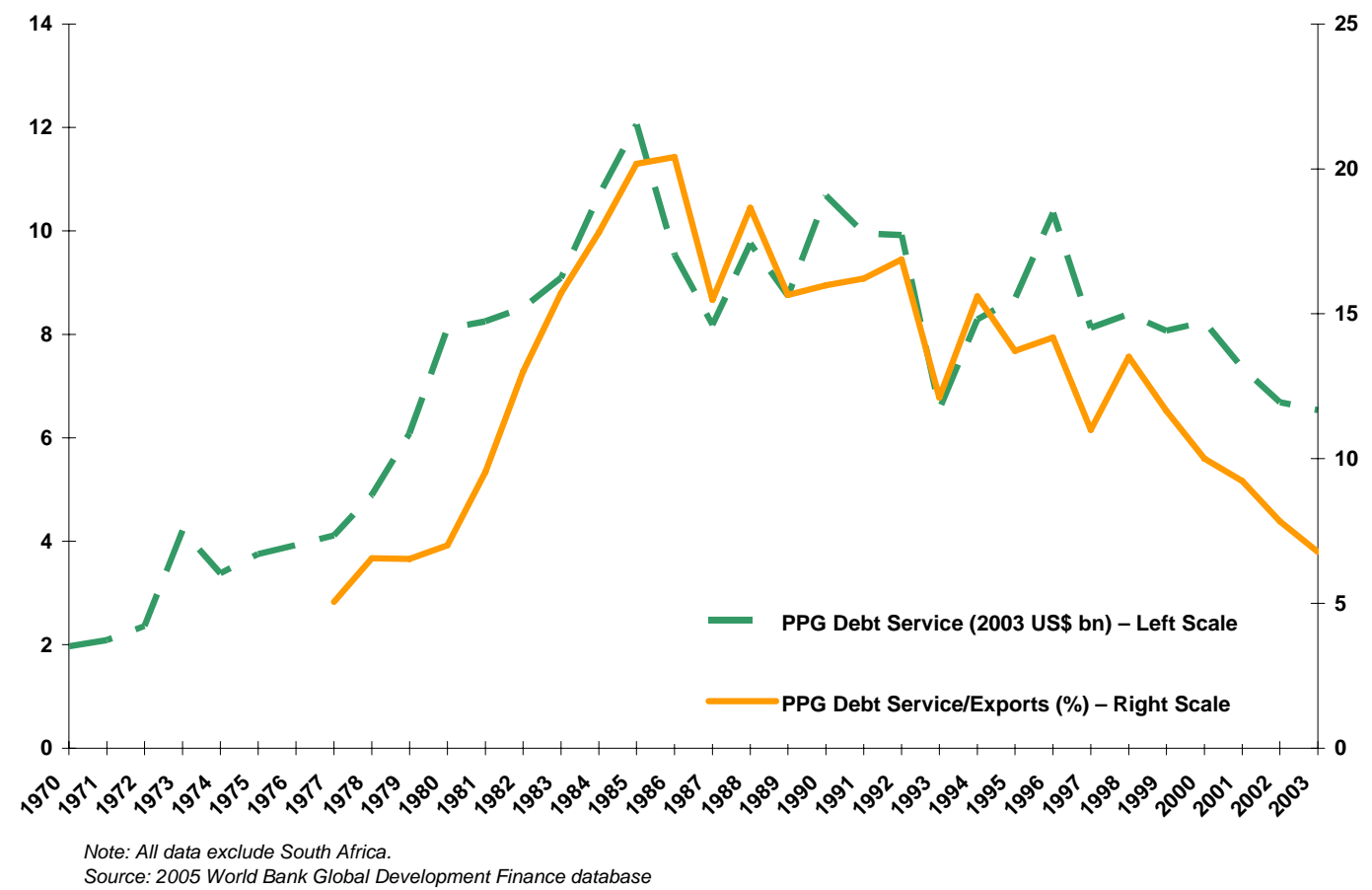


For many of the larger developing countries which have faced debt crises, such as Mexico and Brazil in the 1980s, the problem can be traced back to unsustainable borrowing combined with rising global interest rates. For nearly all African countries, however, the story is very different. Few African governments have had access to private capital markets and almost all their borrowing has been from official sources, such as bilateral donors (like the UK or Japanese governments) or the multilateral agencies, especially the World Bank, IMF, and the AfDB. Unlike private creditors, these institutions provided loans at very low fixed interest rates with long grace periods. For example, the loan terms for the International Development Association (IDA, the lowincome window at the World Bank) are 40 years at 0.75 percent interest and a ten year grace period.

Instead, Africa's debt problems are mainly the result of slow economic and export growth, combined with the perverse effects of the international aid system. Countries borrowed funds on extremely soft terms, but they were still unable to repay the loans because those investments never produced the expected gains. Thus the rise of Africa's debt ratios (debt stock/GNI or debt service/exports) is in many ways not so much a problem with the numerators growing too fast as it is of the denominators growing too slowly (or for many countries not at all). This is why there is very little divergence over the past three decades between the absolute figures and the ratios.

Africa's real growth of GNI has averaged just 1.1 percent since 1970, far less than population growth. If the region had instead grown at a modest 3 percent (assuming borrowing was the same), its current debt would be just 37 percent of GNI instead of 70 percent. If the region had grown at 5 percent, the ratio would drop to only 19 percent (Figure 3). Repeating this exercise for exports shows similar results, with the debt service ratio dropping from the actual rate of 6.8 percent of exports to only 3.7 percent if export growth had been a modest 3 percent. It is true that long-term secular declines in the prices of some commodities produced by African countries may have suppressed export levels and exacerbated the problem. But the most important factor in the emergence of the African debt problem has been the underlying lack of expansion in real income or exports. 
Figure 3

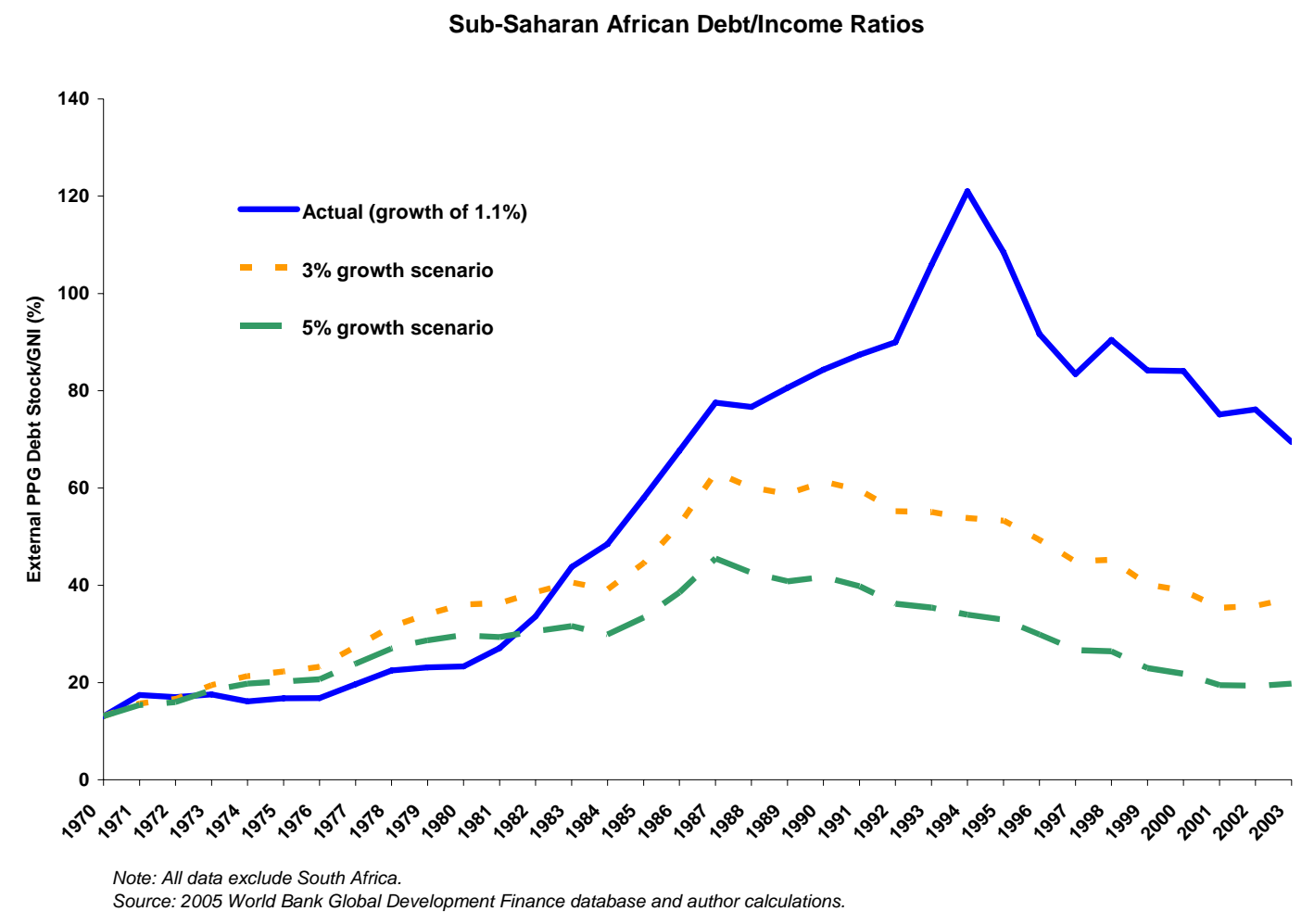

Another factor in Africa's debt burden has been the way donors, and the multilaterals in particular, allocate loans. Most of the bilateral donors have shifted from loans to grants, leaving the World Bank and the AfDB as the main source of loans for many African countries. IDA, for example, uses a score, the Country Policy and Institutional Assessment (CPIA), to skew its resources toward better performing countries. This makes operational sense, but since IDA is a fixed pool of resources that gets distributed each year based on the CPIA, there is no consideration of any country's particular debt sustainability. The part of the World Bank that worries about debt levels is not the same part that determines new lending. Ironically, this results in some of the best-performing countries-Tanzania, Uganda, Ghana, Mozambique-requiring the most debt relief. The Bank hopes to avoid repeating this problem in the future by increasing the use of grants within IDA and by implementing a new framework linking debt levels to new lending (IMF/IDA, March 2005).

\section{Past debt relief}

As early as the 1970 s, bilateral creditors began writing off debts to some low-income countries. Over time, the Paris Club of official creditors added ever softer terms for lowincome countries: Toronto terms provided 33\% debt stock reduction in 1988, London terms of $50 \%$ in 1991, Naples terms of $67 \%$ in 1994, and then Cologne terms of $90 \%$ in 
1999. Most African countries used these facilities to restructure and reduce their debts in the 1980s, with many countries returning to the Paris Club repeatedly. Indeed, between 1980 and 2000, 17 African countries reached six or more different agreements with the Paris Club. Many of the bilateral creditors also went a step further than Cologne terms and gave $100 \%$ write-offs.

By the mid-1990s, Paris Club reductions did not seem to be achieving the aim of debt sustainability and the calls for more widespread relief were mounting. The new president of the World Bank James Wolfensohn, whose tenure began in 1995, was also convinced that more needed to be done to help poor countries cope with their debt problems. The following year, the Bank and the IMF, both of which had resisted debt relief in the past for legal and practical reasons, conceded and created the Heavily Indebted Poor Countries (HIPC) initiative.

HIPC provides extra relief for those countries that still exceed a defined debt sustainability threshold (mainly a debt stock-to-export ratio above 150 percent) after a Paris Club write-down of bilateral stock. If a country qualifies and meets other performance criteria, they are deemed to reach 'decision point,' where interim relief is provided. If the country stays on track with its reforms and shows that any savings from debt relief are being used wisely, then the country can reach the 'completion point,' which is for irrevocable relief with permanent write-downs of debt stock. In 1999 the HIPC initiative was enhanced further and the terms were softened again. Uganda was the first country to benefit from HIPC, entering the program in 1997 and reaching completion point in May 2000. As of May 2006, 40 countries are HIPC-qualified (33 of which are African) and 19 of these (15 African) have reached completion point (See Table 1). There are eleven 'pre-decision point' countries, which could still qualify before the current sunset of HIPC at the end of $2006 .^{3}$

\footnotetext{
${ }^{3}$ Eritrea, Kyrgyz Republic, and Haiti were added in 2006 and Laos and Burma were removed.
} 
Table 1: HIPC countries, as of May 2006

\begin{tabular}{|c|c|c|}
\hline Completion Point & Decision Point & Pre-Decision Point \\
\hline $\begin{array}{l}\text { Benin } \\
\text { Bolivia } \\
\text { Burkina Faso } \\
\text { Cameroon* } \\
\text { Ethiopia } \\
\text { Ghana } \\
\text { Guyana } \\
\text { Honduras } \\
\text { Madagascar } \\
\text { Mali } \\
\text { Mauritania** } \\
\text { Mozambique } \\
\text { Nicaragua } \\
\text { Niger } \\
\text { Rwanda } \\
\text { Senegal } \\
\text { Tanzania } \\
\text { Uganda } \\
\text { Zambia }\end{array}$ & $\begin{array}{l}\text { Burundi } \\
\text { Chad } \\
\text { Congo, Rep. } \\
\text { DRC } \\
\text { Gambia } \\
\text { Guinea } \\
\text { Guinea-Bissau } \\
\text { Malawi } \\
\text { Sao Tome and Principe } \\
\text { Sierra Leone }\end{array}$ & $\begin{array}{l}\text { Central African Republic } \\
\text { Comoros } \\
\text { Cote d'Ivoire } \\
\text { Eritrea } \\
\text { Haiti } \\
\text { Kyrgyz Republic } \\
\text { Liberia } \\
\text { Nepal } \\
\text { Somalia } \\
\text { Sudan } \\
\text { Togo }\end{array}$ \\
\hline
\end{tabular}

\section{The MDRI}

Despite increasingly generous debt relief programs and nearly a decade of HIPC, many of the participating countries were still complaining about debt service obligations. Because bilateral debt was reduced through the Paris Club and most of the bilateral creditors have now switched from loans to grants for the poorest countries, the remaining piece of HIPC debt was owed mainly to the multilateral institutions (Figure 4). Thus, in 2005 the major economic powers - which also happen to be both the main creditors and the controlling shareholders at the multilateral institutions - agreed to tackle this residual debt once and for all. The Commission for Africa (2005), chaired by Prime Minister Tony Blair, also called for 100 percent debt cancellation for sub-Saharan Africa. These trends all helped bring about a major conceptual shift: for the first time, the major international financial institutions accepted the premise of moving toward full debt relief. 


\section{Figure 4}

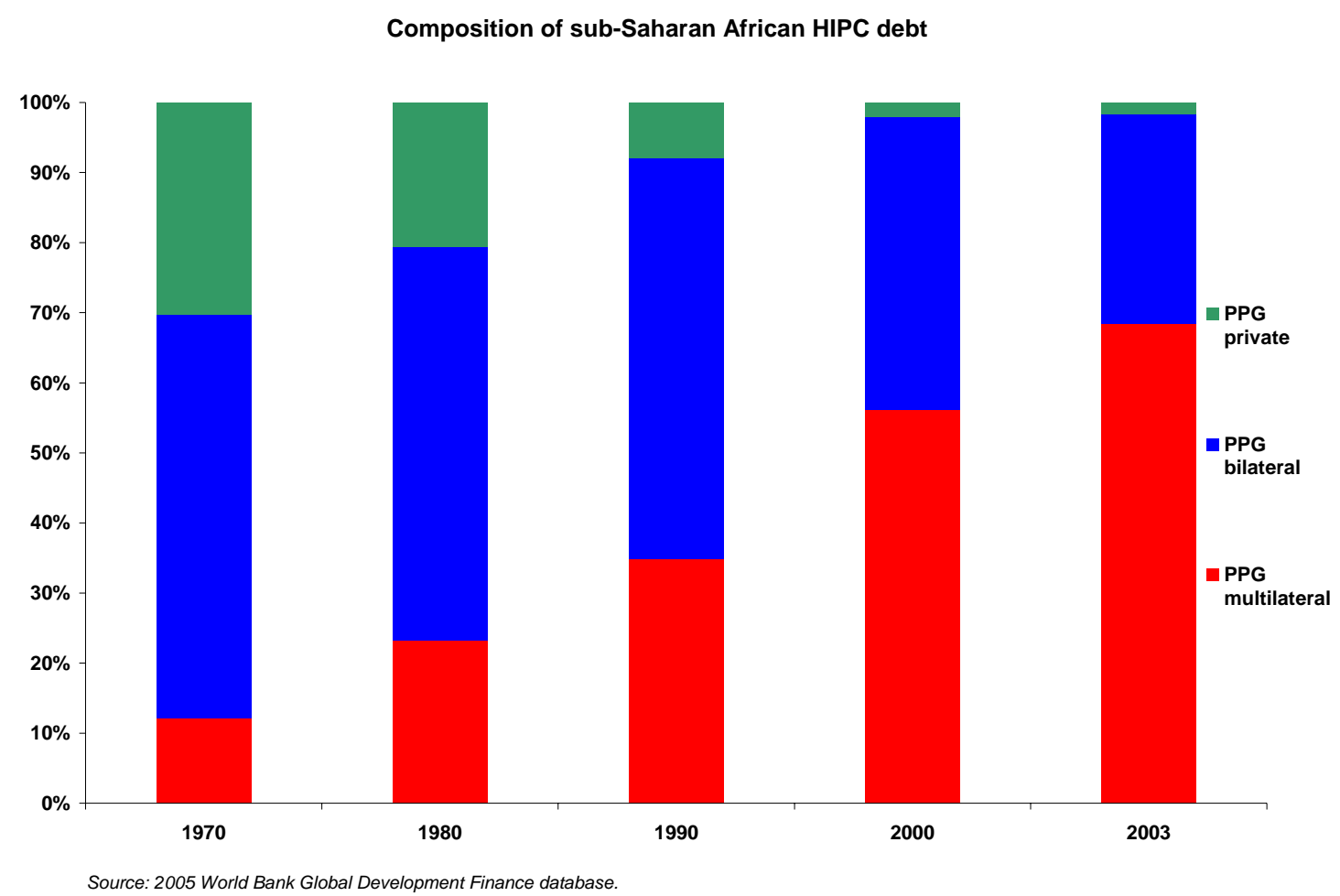

In the lead up to the G8 Summit at Gleneagles, it was clear that some new mechanism was likely to emerge. The UK proposed that the donors assume responsibility for debt service and just make payments to the multilateral institutions on behalf of the indebted countries. They argued that this would free resources in poor countries to spend on other priorities and that it would also ensure 'additionality'. The US made an alternative proposal also to move to 100 percent relief, but to have the World Bank and IMF cover the lost income from internal resources. The Bush administration suggested that the Bank simply net out any debt service from new IDA credits to each country. The main benefit of this option was that, unlike the UK plan, the debt itself could be taken off the books, cleaning up the accounts for both the creditors and the debtors. The effect on cash flow for debtor countries would be neutral and it was thought more politically viable since it would also not have any budget implications for the donors. (A third European proposal was also floated which tinkered with the existing HIPC debt sustainability threshold, but this was rejected by both the UK and the US.)

Ahead of Gleneagles, a compromise was reached. The eventual MDRI is based largely on the US proposal, but also includes additional resources 'dollar for dollar'. Some of the non-G8 members, along with World Bank staff, had raised strenuous objections to the plan, claiming that it might imperil the Bank's future financial health since there was no guarantee that shareholders would cover any lost revenue. The US had initially dismissed any such concerns since reflows from HIPCs represented such a tiny proportion of Bank income, but the Europeans maintained that it might become a 
problem in the future. This final hurdle was overcome at the last minute through the signing of an extraordinary letter by the leading finance ministers pledging to compensate the World Bank for any lost future income from forsaken reflows. (There is no such provision for the IMF, which is expected to use resources from previous gold revaluations and other internal resources.) The major shareholders also have tried to avoid some of the problems of re-lending to HIPC countries by creating an expanded IDA and AfDB grant window for the poorest and most-indebted.

\section{What should we expect from the MDRI?}

The MDRI achieves what debt campaigners might have thought impossible just a few years ago: close to full debt relief for some of the world's poorest countries. ${ }^{4}$ What then are reasonable expectations of the effect of this achievement for the previously-indebted countries? A good place to start is to assess the various costs of high debt which should soon be lifted. 'Drop the debt' was always partly a moral argument that it was unconscionable for poor countries to pay money to rich ones. But proponents also made a more practical claim that money spent on servicing debts took away resources from other priorities, such as social services. Additionally, there are three other areas where high levels of debt are thought to have possible negative effects and where debt relief might therefore have a lasting positive effect: growth, policies, and institutional development.

\section{Social services and poverty}

Activist appeals for debt relief are typically justified on the basis of diverted resources, thus the common comparison by Jubilee, Oxfam, and other campaigners of the size of debt service versus other spending such as education or health care. The implied argument here is three-fold: (1) countries unwillingly spend money servicing debt that would otherwise be used on social services; (2) money is a crucial binding constraint on raising welfare; and (3) the size of debt service is big enough to have a meaningful effect on those outcomes. If these are all true, then nearly 100 percent debt relief should lead not only to vast increases in social services spending, but also have an immediate positive impact on poverty rates and other developmental indicators.

Unfortunately, there are problems with all three propositions. There is some evidence that social service spending has risen following debt relief in the past. The IMF for instance claims 'poverty reducing expenditures' in HIPCs has gone up from 6.4 percent of GDP in 1999 to 7.9 percent in 2004. However, it is far from clear that this is the result of debt relief given the increasing trend of donor earmarking for social services. This is non-trivial since aid inflows average nearly 60 percent of total public expenditure in the 15 sub-Saharan completion point HIPCs.

\footnotetext{
${ }^{4}$ In practice, countries will not get 100 percent relief because the MDRI does not cover commercial debt or any residual bilateral debt. In addition, the multilateral portion has cut-off dates for eligible debt stock, end-2004 for the IMF and the AfDB and end-2003 for the World Bank.
} 
Second, there is an extremely weak connection between expenditure and development outcomes. Greater health care spending does not mean better health and more money for schools does not necessarily mean more kids in school. Empirically, there is no relationship between, say, average expenditure on education and school enrolment or between health expenditure and child mortality. There is a long literature exploring this apparent paradox, with most of the evidence pointing toward problems deeper than funding levels, such as weak management, poor quality services, and in some cases low demand (Filmer, Hammer and Pritchett, 2000). Whatever the reason in each country, it simply cannot be assumed that shifts in spending from debt service to social services, if it occurs, will lead to vastly improved living conditions for Africa's poor.

Third, the scale of resources involved in the MDRI is relatively small. Although HIPCs have been complaining loudly about the burden of servicing World Bank debt, the size of such flows has in reality been almost insignificant. The 15 African HIPCs paid on average \$19 million in debt service to IDA in 2004. But that same year, they received on average \$197 million in new IDA credits and \$946 million in total aid. In other words, the debt service they paid to the World Bank was less than one-tenth of what they received from the Bank in new money and less than one-fiftieth of all aid inflows. This suggests that the short-term increase in resources from the cancellation of IDA debt obligations would be on the order of 2-3 percent of total aid receipts. Since aid flows to these countries over the past decade has typically fluctuated (up or down) by about $\$ 150$ million per year, it is difficult to imagine that the savings will make a palpable difference. ${ }^{5}$

\footnotetext{
${ }^{5}$ Although these figures suggest that the financial impact on HIPCs from the MDRI will be negligible in the short-term, the effect could grow over time; by some World Bank estimates (subject to various assumptions), the overall cost could possibly reach about six times current levels by 2026 .
} 
Table 2: Resource flows to African HIPCs, 2004 (US\$ millions)

$\begin{array}{lrrr} & \text { IDA debt service } & \text { New IDA inflows } & \text { All ODA } \\ \text { Benin } & 11 & 37 & 378 \\ \text { Burkina Faso } & 9 & 130 & 610 \\ \text { Cameroon } & 19 & 97 & 762 \\ \text { Ethiopia } & 21 & 476 & 1823 \\ \text { Ghana } & 39 & 288 & 1358 \\ \text { Madagascar } & 24 & 308 & 1236 \\ \text { Mali } & 17 & 70 & 567 \\ \text { Mauritania } & 6 & 42 & 180 \\ \text { Mozambique } & 5 & 194 & 1228 \\ \text { Niger } & 6 & 72 & 536 \\ \text { Rwanda } & 5 & 144 & 468 \\ \text { Senegal } & 29 & 166 & 1052 \\ \text { Tanzania } & 41 & 474 & 1746 \\ \text { Uganda } & 30 & 300 & 1159 \\ \text { Zambia } & 16 & 156 & 1081 \\ & & & \\ \text { average } & 19 & 197 & 946\end{array}$

Source: OECD, World Bank

In addition to the small scale of the potential savings from debt relief, it is also clear that there will be no financial windfall for qualified countries from the MDRI by design. As per the agreement, any savings from forgiven IDA debt service obligations will be netted out of future IDA flows to that country. Since IDA is allocated through a formula including a measure of poverty and the CPIA performance score, countries will earn a theoretical IDA allocation but actually only receive that amount minus what they would have repaid IDA had the debt not been cancelled. The compromise for extra resources kicked in by the donors stipulates that this additional funding is not earmarked for those specific countries, but rather goes into the general IDA pool for allocation through the normal channels. Since many of the HIPCs are also among the top scorers on the CPIA they may see an increase from the slightly larger pooled reflows, but since this pool goes to more than 60 countries, any increase will necessarily be significantly smaller than their individual debt service savings.

\section{Economic growth}

A large literature has addressed the links between debt and economic growth (Pattillo, Poirson and Ricci, 2002). The most common explanation is the so-called 'debt overhang' whereby a high debt burden dampens the incentive to invest because investors expect that distortionary measures may be taken such as higher future taxes. This delays potential investment, discourages long-term investment in productivity, and can create liquidity shortages. Despite these possible channels, empirical studies have failed to identify whether such a debt overhang exists, with the evidence particularly unclear for the low- 
income countries (perhaps because they receive so little private investment). Given this ambiguity, hopes for a significant boost to HIPC country growth rates from the latest debt deal appear unrealistic.

\section{Policy reform dynamics}

Unsustainable debt is itself an indicator of poor management and weak policies. Indeed, all of the HIPCs are in the midst of major economic reform efforts of some kind. However, the presence of high debt and debt service obligations may create policy pressures that undercut some of those very reforms by distorting policy dynamics, such as encouraging an overly short-term orientation or a weakening of public support for reforms. The nearly full debt cancellation possible under the MDRI could therefore provide a boost to the recipient governments undergoing reform, especially if lingering debt has been a barrier to pushing through changes. However, there is little evidence that past debt relief has led to detectable policy improvements, again suggesting that the short-term outcome is likely to be modest (Chauvin and Kraay, 2005).

A potentially important effect on policies from full debt cancellation could be on the creditor side. There is strong evidence that creditors engage in defensive lending (making new loans mainly to cover old ones) and that this undermines the ability of donors to be selective in their allocations (Birdsall, Claessens and Diwan, 2002). If the debt is no longer a factor in lending/grant decisions, then donors could find it easier to direct their resources to better-performers and to withdraw assistance from nonperformers. Although it is merely speculation at this point, this could be a strongly positive effect. (If this does occur, it could be another unexpected outcome for debt relief campaigners who have generally advocated softer donor treatment, not tougher selectivity enforcement.)

\section{Institutional development}

High debt, through the contribution toward ongoing fiscal crises and by the heavy administrative burden on weak public institutions, may also impede the development of capable states (Radelet, 2005). Many of the HIPCs not only face capacity constraints in public administration and budget management, but they often struggle even to provide basic public services. Debt management is one essential if complex responsibility of the state and requires high levels of technical skill and political influence. Measuring the administrative cost of managing debt is difficult, but Paris Club rescheduling is one possible proxy. Each time a country goes to the Paris Club it involves a huge set of analytical, legal and negotiating skills monopolized for months at a time. Unsurprisingly higher debt countries return to the Paris Club more often (Moss and Chiang, 2003). Senegal has sought rescheduling 13 times since 1980, while Madagascar and Niger have done so 10 times apiece. Much of the time and effort committed by public officials to debt could now be redeployed in other more productive areas. Although this is conjecture, this might have a positive long-term impact on state capacity. But even in a best case scenario, such benefits would not become evident for many years and the cause would be hard to attribute. 


\section{Conclusion}

The new MDRI will significantly cut the debt stock levels of a core set of indebted lowincome countries. It is likely that neither HIPC nor the MDRI would have been agreed had anti-debt activists not used emotional appeals to poverty reduction to build support. Juxtaposing debt service against social services and high levels of need in poor countries has undoubtedly been politically effective, both with the wider public and with policymakers. However, the actual short-term financial impact for the affected countries is unlikely to have a meaningful effect on either government finances or on poverty reduction anytime soon. The numbers are simply too small and finances are often not the binding constraint. In other words, debt relief is not likely to have a huge effect because the debt burden was never as harmful as campaigners frequently claimed and the channels in which debt affects development are different than commonly believed. This is not to say that the MDRI is not a good idea, but rather that most of the impact, if any, will be long term and difficult to measure. As such, expectations of the effect on indebted countries and development indicators should be kept modest and time horizons long. 


\section{References}

Birdsall, Nancy, Stijn Claessens and Ishac Diwan, "Policy selectivity foregone: Debt and donor behavior in Africa," CGD Working Paper 17, Center for Global Development, Washington DC, 2002.

Chauvin, Nicholas and Aart Kraay, "What has 100 billion dollars worth of debt relief done for low income countries?" Mimeo, September 2005.

Commission for Africa, Our Common Interest, London, 2005.

Filmer Deon, Jeffrey Hammer and Lant Pritchett, "Weak Links in the Chain: A Diagnosis of health policy in poor countries," World Bank Research Observer, Vol. 15, No. 2,2000 .

International Monetary Fund and International Development Association, "Heavily Indebted Poor Countries (HIPC) Initiative: Status of implementation," Washington DC, August 19, 2005.

International Monetary Fund and International Development Association, "Operational Framework for Debt Sustainability Assessments in Low-Income CountriesFurther Considerations," Washington DC, March 28, 2005.

Moss, Todd and Hanley Chiang, "The Other Costs of High Debt in Poor Countries: Growth, Policy Dynamics, and Institutions," HIPC Unit Issue Paper on Debt Sustainability, World Bank, Washington DC, 2003.

Pattillo, Catherine, Hélène Poirson and Luca Ricci, "External debt and growth," IMF Working Paper 69, International Monetary Fund, Washington DC, 2002.

Radelet, Steven, "Chance to break free from cycle of debt," Financial Times, London June 30, 2005.

World Bank, Global Development Finance, Washington DC, 2005. 